Meta

Journal des traducteurs

Translators' Journal

\title{
On the Implausibility of Equivalent Response (Part V)
}

\section{Qian $\mathrm{Hu}$}

Volume 39, numéro 3, septembre 1994

URI : https://id.erudit.org/iderudit/003149ar

DOI : https://doi.org/10.7202/003149ar

Aller au sommaire du numéro

\section{Éditeur(s)}

Les Presses de l'Université de Montréal

ISSN

0026-0452 (imprimé)

1492-1421 (numérique)

Découvrir la revue

Citer cet article

$\mathrm{Hu}$, Q. (1994). On the Implausibility of Equivalent Response (Part V). Meta, 39(3), 418-432. https://doi.org/10.7202/003149ar
Résumé de l'article

Dans ce cinquième et dernier article, l'auteur fait le bilan des études antérieures sur l'équivalence et s'attache à montrer l'importance et la variabilité de la notion de compréhension : elle n'est pas simplement un acte cognitifmais une variable modifiable par l'expérience et la culture. d'utilisation que vous pouvez consulter en ligne.

https://apropos.erudit.org/fr/usagers/politique-dutilisation/ 


\section{ON THE IMPLAUSIBILITY OF EQUIVALENT RESPONSE (PART V)}

QIAN HU

Monterey Park, California, USA

\section{Résumé}

Dans ce cinquième et dernier article, l'auteur fait le bilan des études antérieures sur l'équivalence et s'attache à montrer l'importance et la variabilité de la notion de compré. hension: elle n'est pas simplement un acte cognitif mais une variable modifiable par l' expérience et la culture.

CHAPTER V

UNDERSTANDING

Communication usually involves three elements - source, message and receptor (Nida 1964: 44). Its role of inter-lingual communication complicates translation in this connexion. Moreover, equivalent response implies parallelism between the responses from both the source language reader and the target language reader. It is therefore insufficient to investigate the putative possibility of solicitation of equivalent response only in the respects of language nature, translation procedure and the interrelationship between content and form. Obviously, an adequate discussion of the possibility of equivalent response requires an approach to the problem in the aspect of understanding.

\section{Understanding: an initiative act}

Understanding is a mental or psychological process. Rosenberg (cited in Grace 1982: 14) defines it as follow:

To understand something is to "give it a 'reading' in terms of which it 'fits' into a larger, coherent, unitary picture of the world."

Rumelhart (1979: 85) makes a similar observation; he thinks that the process of understanding involves

selecting and verifying conceptual schemata to account for the situation (including its linguistic components) to be understood. Having selected and verified that some configuration of schemata offers a sufficient account for the situation, it is said to be understood... a "schema" is taken to be an abstract representation of a generalized concept or situation, and a schema is said to "account for a situation" whenever that situation can be taken as an instance of the general class of concepts represented by the schema ${ }^{1}$.

According to the above definitions, understanding is not a merely passive act of receiving information. It involves effort on the part of the decoder. In fact, it is an initiative act which is characterized by hypotheses and presuppositions emerging in the process. An American-Chinese linguist (Chao 1980: 152) points out:

When one reads, one does not read word by word, not even sentence by sentence. Usually, having read one sentence in a context, one can roughly guess in which direction the next sentence will move. Occasionally, of course, some writers may deliberately turn in an unexpected direction so that the reader will be surprised. The reason why the writer's expression is beyond the reader's expectation is that the reader has had something to expect, otherwise nothing could exceed his expectation. 
For example, it is not surprising to find $e g g$, bacon, and coffee under the heading breakfast on a menu, because the heading evokes a set of expectations (Widdowson 1983: 30). But if roast turkey is listed there the reader would be confused as nobody normally expects to eat this for breakfast. To have certain expectations is, in Widdowson's term (1983: 30), to be engaged in a certain frame of reference. In the above case, egg, bacon and coffee are predictable items when "the breakfast frame of reference" is engaged, whereas roast turkey is subconsciously excluded.

In addition to presuppositions, hypotheses also occur in the process of comprehension, and they are imposed on the perceived linguistic signals. In communication, for instance, the receptor often "encode a message on his own which he presumes to be more or less parallel to what the speaker is saying," rather than decodes the utterances (Nida 1964: 122-123). The messages thus encoded may be misleading, but the initiative act performed is essential to the process of comprehension on the part of the receptor, and to the process of communication in general. For the receptor is not, as was once assumed, a consumer, but a producer of a discourse (Bassnett-McGuire 1980: 79). When receiving a linguistic signal, he spontaneously makes a personal contribution to it, and, in fact, an adequate understanding will not be reached until that contribution has been made. Grace (1982: 10) argues that:

no sentence really says all that the speaker intends to be understood from it. In fact, no sentence says enough to be understood at all without a contribution from the audience.

So the receptor's initiative is actively required in the process of comprehension. Further evidence of receptor initiative is in the understanding of such lines as "Zhŭren xiàmă kè zàichuán" (host dismount horse guest in boat), which does not mean "the host dismounted from his horse while the guest went in the boat," but "both the host and the guest dismounted from their horses and went in the boat" (Yang D. Y. 1985: I, 14-15). Of course, it would be absolutely correct to interpret it as "the host dismounted from his horse while the guest went in the boat," but only if this interpretation were consistent with the understanding of the whole poem. It is inappropriate to interpret this way, because this interpretation does not conform to the general understanding of the poem. Consequently, the interpretation is adjusted by turning it in another direction and attempting to bring out a coherent understanding of the poem.

Linguists and rhetoricians call this linguistic phenomenon hùwēn, explaining for us that the subject in either of the two subject-predicate constructions actually governs the predicates in both the constructions, and that, similarly, each of the two predicates actually comments about the two subjects in question. They take hùwen as a rhetorical device (Yang D. Y. 1985: I, 14-15). In fact, hùwēn is a defect of Classical Chinese in its capacity of expression, due to the constraints of this particular genre as well as of the language itself. The reader's understanding, however, contributes to fill the gap, enforces the capacity of expression of the language, finally turning the defect into a rhetorical device. Due to its inherent property as a code system, language is extremely powerful in its potential capacity for expression, but its power would be considerably reduced if human understanding depended on a passive reception.

Yet it seems that our understanding is instinctively initiative; this claim may be verified by observation of patients with brain damage. Scientists studying patients with brain lesions have discovered a paradoxical phenomenon; patients with difficulty in understanding the meaning of individual words, and patients capable of memorizing only one or two words or phrases, are actually capable of grasping the general message of a text as a whole. One explanation of this paradox which these scientists offer is that "these patients continue to make active* attempts to decode the communication" and these attempts are 
thought to enable the patients to grasp the general sense of the communication (Luria 1981: 235-236).

Rumelhart's (1979: 85) description of comprehension is remarkably illuminating, with a strong emphasis on the initiative effort by the decoder in an act of understanding:

...comprehension, like perception, should be likened to Hebb's paleontologist who uses his beliefs and knowledge about dinosaurs in conjunction with the clues provided by the bone fragments available to construct a fully-fledged model of the original.

In the case of communication,

the words spoken and the actions taken by the speaker are likened to the clues of the paleontologist, and the dinosaur, to the meaning conveyed through those clues. On this view, the processing is much more "top down" in that internal hypotheses are actively imposed on the observed utterances. ${ }^{*}$

It is in this sense that Luria (1981: 170) claims that the main property of the comprehension process is exploration. He argues that exploration "leads to a selection from a number of alternatives." As each receptor explores a text or a discourse "according to a different set of systems," the idea of one correct interpretation is dissolved (Bassnett-McGuire 1980: 79).

According to Grace (1982: 14), underlying any speach act there is an understanding that the speaker intends to elicit by means of the linguistic sign which he employs. This understanding which he calls the speaker's meaning is defined as the "understanding which the speaker intends to produce in the particular audience by means of the recognition by the audience of that intention." This concept of the speaker's meaning and that of exploration suggest that the creation of meaning or rather the establishment of contentform entity is not completed until the process of communication is completed. The entity is not set up at the stage of encoding on the part of the encoder, but created through the dynamics of complete process of communication ranging from encoding to decoding.

It can then be postulated that when he encodes, the encoder indicates the way to arrive at his intended understanding. For various reasons he does not - or cannot produce an adequate understanding and impose it on the decoder; on the contrary, he may even be forced to leave gaps for the decoder to fill in. He could be likened to a guide who is able to explain how to reach a particular destination by heading in certain direction, but he cannot accompany others or go there instead of them. Nor can he even ensure that they follow the route which he has indicated. When he decodes, the decoder may or may not follow the indication; but no matter how he decodes, certain subjective factors, such as internal hypotheses and presuppositions, will inevitably get involved in the process. He uses his experience, beliefs and his general knowledge to fill the gap and so obtain an adequate understanding. The obtained understanding (his interpretation of the intended understanding) will unavoidably be affected or coloured by the initiative effort made in his process of decoding. Not only can more than one correct interpretation exist, but also there are no two absolutely compatible interpretations of the same discourse. Every interpretation is unique, because every decoder decodes in a unique way: no two persons share exactly the same experience, the same beliefs and the same knowledge.

\section{Understanding and language}

As a process, understanding begins with the perception of a speach signal characterized by phonological, lexical-morphological, and logical-grammatical structures. The perception of a speach signal triggers off the process of understanding, which is then engaged in deciphering linguistic codes (Luria 1981: 233). Though initiative, understanding develops in reaction to the stimuli of linguistic codes. It does not dart about at random 
but proceeds in a direction indicated by the linguistic codes that it tries to interpret to the full. Although other factors may come in, the whole process of understanding generally operates on an axis of the perceived linguistic codes. Even the active attempts to grasp the general sense of communication made by the patients with brain lesions are based on the utilization of certain (formal) linguistic features; that is, they are based on "the retention of the intonational-melodic structure of the message and on residual sense bits" (Luria 1981: 235-236). If their mental ability allowed no such utilization of these (formal) linguistic features, their attempts, however active, would be in vain; in fact, it is doubtful if they would occur at all without stimulation. ${ }^{2}$ So, an adequate understanding of a text or a discourse can only be reached through the recognition of its literal components (cf. Blooms 1981: 75-76); (formal) linguistic features to a greater or lesser degree serve as a guide that pilots the reader/hearer in his exploration through the text or discourse of which they are constituent elements (cf. 1981: 46).

As understanding is to some extent directed by linguistic features, it is unavoidably affected by the language concerned. ${ }^{3}$ Leo Wiesgerber (cited in Steiner 1975: 86) states succintly that "our understanding is under the spell of the language which it utilizes." In agreement with him, Whorf (1956: 147) notes that every language forms or creates a thought world, a microcosm, that "each man carries about within himself, by which he measures and understands what he can of the macrocosm." Their observations concerning understanding reality apply equally to the comprehension of messages communicated in words. Understanding verbal communication is an integral part of understanding reality, because verbal communication not only reflects reality, it is part of reality itself. Language as a social phenomenon is itself also part of reality, despite the fact that it is used to segment and measure reality - including language itself.

For instance, the understanding of an utterance or even a word is not merely based on the syntagmatic structures in which it occurs. It is also influenced and amplified by the paradigmatic structures where the utterance or the word is conventionally related to other linguistic elements; the understanding elicited only by the syntagmatic structure is often

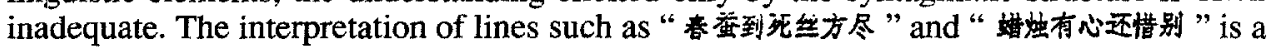
case in point. Without those paradigmatic structures in which the characters “死," “丝”" and " $心$ " happen to be associated in one way or another with other characters such as “靑” "and "芯," our comprehension of these two lines would lack depth, and be very different from the understanding actually elicited in our brains.

The impact of language on understanding is obscured by the confinement of observation to one language; in the case above, it is limited to Chinese. If the comprehension of the two lines in Chinese is compared with that of their renderings in English, the argument will be more forceful and convincing. If the syntagmatic structures of the two lines could be exactly reproduced in English, ${ }^{4}$ the English renderings might elicit an understanding from the audience which is similar to that occuring in the comprehension of the original lines to the extent that the renderings succeed in producing a general message, similar to that contained in the original. But, undoubtedly, the English understanding has far less depth in semantic content. The reason obviously lies in the fact that, although the English renderings produce similar syntagmatic structures with corresponding linguistic elennents, they cannot create similar paradigmatic structures which are very arbitrary and conventional, and so are entirely language-specific. In English there are different paradigmatic structures which admit of no understanding that can associate death and silk with thinking of, or wick with heart in sound, orthography, or in any other way, which could create poetic imagery and delightful cadences. This example confirms that understanding of verbal communication is guided — and consequently influenced — by the language it employs. It also proves that to understand a verbal discourse is "to give it a reading" not 
only - if necessary — "in terms of which it fits into a larger, coherent, unitary picture of the world," but also in terms of a complicated system of linguistic codes to which it belongs.

Paradigmatic structures in one language can rarely be produced in another, unless by chance (if, indeed it is conceded that syntagmatic structures can be exactely produced in an alien linguistic environment), for they are arbitrarily formed and as a result they are language-bound. As it has been shown, both types of structures are concerned in the elicitation of an understanding. It follows that corresponding utterances or texts in different languages, no matter how equivalent they seem, evoke different understandings. Different understandings occur in reaction to the stimuli of the equivalent expressions in different languages, because the impacts they receive from the languages they employ respectively are different.

The way transferred words are understood is also evidence that understanding is affected by the language concerned. In the Navaho language, for instance, the spectrum of light is covered by the three terms, dicíi?, dico and doot/'iž, while in English it is divided into six terms red, orange, yellow, green, blue and purple (Catford 1965: 43). The two languages segment the spectrum quite differently, as is roughly shown in the following diagram (1965: 51):

\begin{tabular}{|c|c|c|c|c|c|c|c|}
\hline \multirow{2}{*}{$\begin{array}{l}\text { Form } \\
\text { Substance }\end{array}$} & $\mathrm{R}$ & $\mathrm{O}$ & $\mathrm{Y}$ & $\mathrm{G}$ & B & $\mathbf{P}$ & \multirow{2}{*}{$\begin{array}{l}\text { English } \\
\text { The spectrum }\end{array}$} \\
\hline & \multicolumn{3}{|l|}{$\mathrm{X}$} & $\mathrm{Y}$ & \multicolumn{2}{|c|}{$\mathrm{Z}$} & \\
\hline Form & \$iciíi? & & dico & \multicolumn{3}{|c|}{ dootl'iž } & Navaho \\
\hline
\end{tabular}

If, for any purpose, the Navaho segmentation is required in English, three new English colour terms are needed, conforming to English phonological expectations to represent the three Navaho terms. Though he denies in principle the possibility of "carry-over into the TL of values set up by formal or contextual relation in the SL," Catford (1965: 43) notes that the formal and contextual meaning of these coined English terms "is derived from membership of a lexical set in Navaho." However, this carry-over of Navaho values into English is in fact an imitation of the Navaho triple segmentation in an ad hoc context or situation. This imitated triple segmentation in English does not make any sense, unless it is based on the traditional six-fold segmentation; the English reader cannot interpret the new segmentation, until he has compared it with the terms which are familiar to him. For example, the sentence "It is bogop (a coined English term for doot/" iž)" (see 1965: 43) is nonsense to the English reader who can only understand it if he can discover its place and range on the traditionally dissected spectrum; in fact, he only understands the Navaho segmentation through his own understanding of the traditional segmentation and can then give it a reading in terms of the traditional segmentation of the spectrum.

The substantial features $\mathrm{x}, \mathrm{y}$ and $\mathrm{z}$ are intended to "represent actual colours present in particular situations, and relatable to the English terms red, green, blue occuring in English texts in these situations." Catford (1965: 51) argues:

The Navaho terms $\$ i c i l$ ' and doot/'iž function as translation equivalents in these situations because they are relatable to the same substantial features $\mathrm{x}, \mathrm{y}$ and $\mathrm{z}$. It is solely this relationship to the same substantial features that justifies their use as translation-equivalents since they clearly have quite different meanings from the English items.

These so-called substantial features, however, are the results of the English segmentation since seen from the angle of the Navaho language, there exist no such substantial features. 
Navaho cannot be aware of the distinction betwen $\mathrm{y}$ and $\mathrm{z}$ and would probably see $\mathrm{y}$ and $\mathrm{z}$ as only one substantial feature. That which in English is seen as two actual colours is regarded in Navaho as only one actual colour. So these colours are not actual, in fact, but they are language-specific. For anyone speaking any language (with the exception of spectrum scientists), the spectrum exists only as a traditional, linguistic segmentation. People are unable to discriminate between colours in unsegmented or exotically-segmented spectrums and the English reader is able to understand the Navaho terms only because he knows how to analogize them to his native segmentation. Similarly, if the Navaho reader wants to understand the English colour terms, he must know how to analogize them to his native segmentation. In his understanding of doot' $i \check{z}$, the English reader will instinctively resegment the range covered by the Navaho term and decide which of the regions, G, B or $\mathrm{P}$, is most closely analogous to doot/' $i z$ used in an ad hoc context. He is relunctant to interpret the meaning of doot/'iž before he redissects it on the basis of his native segmentation. Likewise, the Navaho reader spontaneously blurs the distinctions between the English terms green, blue and purple, because to him, they are only one actual colour, relatable to only one substantial feature.

\title{
3. Understanding, culture and experience
}

Apart from the language involved, culture and experience also play a large part in the process of understanding. Understanding does not occur in a vacuum but it always proceeds from the context of a given cultural setting. An indigenously cultural item can be interpreted by a native speaker with no concious effort of understanding, since his background has provided him with sufficient cultural knowledge for the comprehension of any such reference. When the same person encounters an item from an alien cultural source, he is immediately aware of his need for a knowledge of the appropriate culture to provide a setting for the unfamiliar information. Provided they can recognise the characters, Chinese readers will have no difficulty in interpreting the saying "Sihăi zhìnèi jië xiōngdì (Within the four seas, all men are brothers)." An English reader, faced with the same aphorism, feels the need of a Chinese historical and cultural framework to assist his understanding. He does not know "what the 'four seas' are, the social status of 'men' (gentlemen?) nor the precise metaphorical value of 'brother"' (Newmark 1981: 142). Chinese readers hardly have any difficulty understanding all this. Similarly, an adequate understanding of Li Po's ${ }^{5}$ famous line "Yänhuã sānyuè xià Yángzhöu"6 also requires both historical and cultural interpretation. Professor Weng X. L. (1981:15) notes that

\begin{abstract}
the reason that "Yânhuā sānyuè xià Yángzhōu" is considered as "a beautiful poetic line forever" lies in the fact that the poet's friend leaves for Yángzhōu — then the most flourishing place of the land - in "March of smoky flowers," when the natural scenery is the most attractive in the year. With either of the given space and time missing, the line will fail to evoke such gorgeous associations in the reader's mind. However, even neither of them missing, such associations may not be able to occur if the reader lacks the necessary knowledge of China's history and culture.
\end{abstract}

The reason for requiring historical and cultural knowledge to understand texts such as "Yänhuã sänyuè xià Yángzhōu" is that they can be fully interpreted only "in terms of certain all-embracing structures of thought, which include pre-emimently the basic presuppositions and tenets" of the native culture (Nida and Reyburn 1981: 10). When they are rendered into another language, they actually enter into alien structures of thought, or, in Kristeva's (cited in Bassnett-McGuire 1980: 79) term, intertextuality. In the new cultural environment, they are likely to be understood in terms of a different framework of interpretation, as Nida (1981: 24-25) argues: 
How the receptors of a translation interpret the form and content of a message depends in considerable measure upon the extent to which they understand the original language-culture setting. If they understand the presuppositions and values and comprehend the meaning of the various behavioral patterns, they will have little or no difficulty in deciding what the original message must have meant to the first receptors. If, however, they lack this information and if they have no ready access to such data, it is inevitable that they will understand the message of the translation only in terms of their own frame of interpretation, in which their own cultural presuppositions and values play a dominant role.

When a bilingual speaker such as a translator decodes a text in the source language, he may not be able to understand it completely "in the light of this language-culture context" (Nida and Reyburn 1981: 21). His native history and culture will insinuate into his process of comprehension as interfering factors, just as his native language habits will consciously or subconsciously affect his way of speaking a foreign language. In fact, people with different cultural backgrounds could hardly share the same interpretative frame based on the presuppositions and values of a given culture. It is therefore quite natural that the understanding obtained by the TL reader is different from that by the SL reader. Campbell (cited in Kelly 1979: 148) notes that:

The exact import of many of the words and combinations of words made use of in the language will never be perfectly comprehended by one who is totally unacquainted with the history of their religion, law, polity, arts, manners, and customs.

No two receptors even brought up in the same linguistic and cultural setting "are ever likely to comprehend and respond to a message in identically the same way," "for no two individuals ever share completely the same linguistic and cultural backgrounds" (Nida and Reyburn 1981: 7). This means that impact on any particular instance of understanding from a given culture is unique in terms of degree and the extent to which culture affects understanding varies from case to case.

In order to elicit equivalent response, Nida involves the translator in a dilemma: on the one hand he asserts in his many books that "the TL reader can only accept the geographical and historical remoteness of the cultural background being presented to him, if that behaviour itself and all imagery connected with it is recast in his own (modern) culture" (Newmark 1981: 45). In the light of this statement, it would appear that Nida would consider a "hearty handshake" a legitimate rendering of "a non-sexual kiss;" similarly European prose would be a legitimate vehicle for Greek epics. On the other hand he is determined that "the translator cannot be expected to so transpose the message linguistically and culturally that it will fit completely within the interpretative frame of the receptor culture," for "to do this would mean to rob the message of its distinctive time-space setting." Besides, "the translator's purpose is not to make the message sound as though the events took place in a nearby town only a few years ago," but "to prevent receptors from misunderstanding what the original receptors understood when they first received the message" (Nida and Reyburn 1981:29). In terms of this argument of his, a non-sexual kiss should be allowed to remain $a$ kiss and the Greek epic should not be recast as modern European prose.

Experience is another major source of impact on understanding. Since understanding is an effort to fit a text into "a larger coherent, unitary picture of the world," experience is inevitably involved. Each person has an individual set of experiences which colour his world, so - in an attempt to understand language - everyone employs an idiosyncratic reading. A child with a naive imagination may perceive the word hurricane as having a pleasurable bracing tone. This is exactly how he was impressed by the word hurricane when the young Sapir read books about the Spanish Main. For the survivors of a hurricane, their personal experience causes the word to evoke the terror entailed by a ruthless 
force of nature (cf. Sapir 1921: 42). Similarly the word home has one meaning to an only child who lives in a nuclear family, and another, quite different, meaning to a child from an extended family in which four - or even five - generations live together, a feature of feudal China (cf. Hong Y. S. 1943: 347-348).

Different sets of beliefs concerning the world, as Jacobsen (1977: 168) observes, may even "lead to different judgements about sentences which are defined by the grammar as being well-formed relative to their presuppositions." Some people would reject the sentence "The dog feels sorry for having bitten you in the leg" as an improbable sentence, while anthropomorphists would consider it to be a normal and acceptable statement (1977: 167).

Personally accumulated knowledge is experience and this has an impact on individual understanding, not only in the sense that it leads to disparity in comprehension, but also in the sense that it sustains communication and understanding. The commonly shared part of experience, which Whorf (1956: 36) calls "the social or collective experience," is embodied in the common linguistic stock of concepts, and it provides a base for communication and understanding. For instance, there is certainly something compatible between the understandings of the word home obtained by the two children through their respective existences. This compatibility constitutes the basic features of the concept home. It is these basic features that make possible the communication and understanding concerning the concept home between the two children who actually lead different existences (cf. Hong Y. S. 1943: 347-348).

\section{Understanding is individual specific}

Because understanding is an initiative act in the process of which certain subjective factors such as internal hypotheses are put into a perceived discourse, because understanding involves its agent's native language habits, cultural background, personal experience, beliefs and education, it varies from person to person, from situation to situation. The reason lies in the fact that no two persons share exactly the same cultural background, experience or beliefs. Regarding this Steiner (1975: 170) observes:

No two human beings share an identical associative context. Because such a context is made up of the totality of an individual existence, because it comprehends not only the sum of personal memory and experience but also the reservoir of the particular subconscious, it will differ from person to person. There are no facsimiles of sensibility, no twin psyches.

From this he concludes:

All speech forms and notations, therefore, entail a latent or realized element of individual specificity. They are in part an idiolect.

If his observation is accepted as true and if his conclusion is seen as valid, then the following assertion made by analogy is also verifiable: All understandings and interpretations, therefore, entail a latent or realized element of individual specificity. They are in part an ideology.

It is this element of individual specificity, as result of given mother tongue habits, cultural backgrounds, personal experience and beliefs, that give rise to disparity in understanding of the same discourse or text. A French writer is quoted by Zeng Xu Bai (1928: 152 ) as saying:

Every word in a book is a magic finger which plucks our cerebral fibres so that they vibrate like strings, and which strikes the tuning forks in our souls so that they produce various notes. But, no matter how skilful and stimulating the artist's fingers are, the quality of the sound produced will eventually depend on the nature of our inner strings. 
So Charles Peirce defines the meaning of a code as the effect which that code produces in the mind of the decoder, indicating that the particular effect differs from person to person (cf. Wang Z. Y. 1982: 3). This definition can very well be extended to a text (or book): the meaning or message of a text is the effect that the text produces in the mind of the reader, and this effect varies from person to person. This does not mean that the text in its own linguo-cultural setting alters in each case; the text remains the same, but the relationship between the perceiving (the reader) and the perceived (the text) alters from instance to instance. This relationship between the text and the reader ${ }^{7}$ is specific in every case, and it always affects the understanding obtained by the reader in question. As a result, "one and the same work will solicit different responses from individual readers who are different from one another" (France cited in Otsuka 1977: 124).

Reading theorists have recently emphasized the relational nature of comprehension. They assume that in the effort to comprehend, the perceived data is related to the individual's knowledge structure and the relevent situation. Therefore, meaning is defined as "relations constructed from the interaction of knowledge relations and a particular environmental context;" understanding is then described "with respect to the quality of the meanings that are activated in that context" (Lovett 1981: 17). These hypotheses are an effort to outline comprehension as a cognitive process with stress on its initiative nature. Of more importance, they see this initiative of comprehension as being relational, selectively connecting the perceived data with the perceiver's knowledge structure and the relevant environment. Their assumption convincingly accounts for the fact that "one and the same work will solicit different responses from individual readers," since the psyche and the personal knowledge structure, to which the perceived data is related and subsequently processed, are unique in each case.$^{8}$ In his description of how a child understands an utterance, Rumelhart (1979: 80 ) presents a similar picture:

When trying to understand an utterance, the child must make use of the situations associated with the various lexical items at hand and try, as well as possible, to construct a cogent interpretation of the utterance (in light of the current context). As a rule, this will involve the extension of concepts from one domain to another. Those extensions may or may not correspond to the intentions of the speaker...

Moreover, comprehension is not plain sailing. "In the reader's mind," Rifateere suggests, "there is a process of 'continual recommencing,' and indecisiveness alternately lost and recovered with each reliving of "revealed significance." This fluctuation makes things "endlessly readable and fascinating" (see Bassnett-McGuire 1980: 90). In addition, the relational nature of semantic structure also makes total reading unending:

Explorations of semantic structure very soon raise the problem of infinite series. Wittgenstein asked where, when and by what rationally established criterion the process of free yet potentially linked and significant association in psychoanalysis could be said to have a stop. An exercise in total reading is also potentially unending (Steiner 1975: 7-8).

In consequence, when the same book is read by the same person, the effect on him, or his response to it, varies from time to time. The second reading is by no means a mere repetition of the first one:

I have read The Reverie of a Lonely Walker again, and we can reread it for a hundred times. Rereading is by no means a simple repetition, for the person who talks endlessly in front of you is so close to you, and his cadenced tone is so changeable, that the book excites you in a new way every time you read it (Gépouneau R. cited in Lin Y. 1986: 4) 
Another factor that partially conditions the reader's response is his reason for reading a specific text. In Lotman's term, it is the positions of the addressee of which he distinguishes four types:

(1) where the reader focuses on the content as matter, i.e. picks out the prose arguement or poetic paraphrase.

(2) where the reader grasps the complexity of the structure of a work and the way in which the various levels interact.

(3) where the reader deliberately extrapolates one level of the work for a specific purpose.

(4) where the reader discovers elements not basic to the genesis of the text and uses the text for his own purpose (see Bassnett-McGuire 1980: 77-78).

This is a broad generalization. In reality, the positions of the addressee are not so clear cut. The reader's intentions are not so categorical; people rarely read for exactly the same purpose - such as may happen in the classroom. Different purposes place the reader at different angles from which he perceives the data. From different angles, he will receive different impact from the perceived data. And his response will occur in reaction to the impact he receives from a particular angle.

To summarize in the light of this brief investigation of understanding, I assert that even if dynamic equivalence, the closest natural equivalence or even full equivalence could be set up in a target language, equivalent response would not be elicited on the part of the TL reader. Between the SL and the TL reader lies the membrane (Steiner 1975: 86) of language and culture that forces them to be stimulated and respond through different channels. As a result, the effects which they receive and the responses that occur in them respectively certainly cannot be equivalent. As comprehension is relevant to experience, intellect, knowledge structure, education and beliefs, which are unique in each case, no two people can respond to one text in exactly the same way, even if they have been raised in the same cultural-lingual climate. It is even impossible for an individual reader to gain the same effects when re-reading a text (see Gépouneau quoted above). As this hypothetical reader experiences different impacts from subsequent readings it would appear unreasonable to assume that his reaction to the same text will be identical. I submit that equivalent response is implausible.

\section{CONCLUSION}

The similarities and dissimilarities between languages have been discussed in the course of the foregoing investigation. The similarities are those characteristics which are shared between all languages and these form a base for translation. The dissimilarities are the individual features of languages which make the equivalent effect of translation impossible. Total compatibility between any two languages is precluded by the very nature of language which is a system of contradictory congruence. This accounts for the fact that translation can always be done but never perfected.

Also the misconception of translation has been clarified. In translation, meaning cannot be transferred from one language into another; the inseparability of content and form denies this widely-accepted assumption. In translation, an SL content-form entity is replaced or substituted by a corresponding TL content-form entity. The message, the meaning and the formal features of the SL text are imitated and relected in the TL text; the TL text creates a message, a meaning and formal features that approximate to those of the SL text. Since translation is not transference of meaning from one language into another but substitution of a TL content-form entity for its corresponding SL entity, equivalent effect is an unattainable goal. 
If the principle of union between content and form repudiates the transference of meaning from one language to another, it also repudiates Nida's model of transfer. His three-stage procedure, where the meaning is supposed to transfer from a source language to a target language on a near-kernel level through transformations, is a method by which dynamic equivalence is to be set up. But transformations involve meaning-changing. Even if meaning could be transferred intact on a near-kernel level, it would be distorted by such a detour by the time it arrived at the TL surface level. The failure of deep structure to determine the meaning of a sentence is another repudiation of Nida's three-stage procedure.

Even if dynamic equivalence could be achieved through Nida's three-stage procedure, equivalent response would be an impossibility. Reading is not merely passive reception; adequate understanding can be reached only when personal contribution is made on the part of the reader. Unavoidably involved in the reader's effort of decoding a message are his cultural background, linguistic habits, level of education, experience and other relevant factors and they will colour the obtained understanding. Since no two people share an identical cultural background, linguistic habits, level of education and set of experiences they will not arrive at the same understanding of a text. The differences between the SL reader and the TL reader in these respects are likely to be even bigger, so the disparities in their understandings will be proportionally greater.

Affected by the receiver's subjectivity, understanding is frequently inconsistent with the source's intention; readers may even extract a meaning or message that the source writer was unaware of while he was writing the text. Consequently, the obtained understanding is called trahison créatrice (Otsuka 1977: 122). Translating is also considered to be a process of trahison créatrice, for it involves the translator's understanding of the original; and therefore the TL audience's understanding of a translation is a two-fold trahison créatrice to the original (1977: 122-123). That is to say, "however precise the renderings may be, they are read in ways unimaginable to both their translators and writers" (1977: 106). This accounts for the failure of the established dynamic equivalence and/or the closest natural equivalence to gain the intended response from the TL audience.

\section{Notes}

1. Cf. Grace (1982: 9):

...the 'symbolic meaning' of a sentence (or any linguistic expression) must be thought of as an abstract representation. In order for an act of communication to be completed the audience must provide this abstract representation with an interpretation. This interpretation is very analogous to the 'interpretation' by which a mathematical calculus becomes a deductive system or eventually part of a scientific theory. A well-formed sentence provides indications - hints, we might say - (for example, by means of devices such as definiteness, anaphora, voice) as to how it should be interpreted. The act of understanding, which involves devising this interpretation, is performed by the audience. It is essentially a putting into context of the abstract representation consisting of an emic situation and conditions of instantiation.

2. Cf. Searle (1970: 123): "...because without using the metaphorical expression, we will not reproduce the semantic content which occurred in the hearer's comprehension of the utterance." $\mathrm{C}$. also note 1.

3. Bloom (1981: 84) mentions in a note the evidence presented by Laitin (1977)

from native Somali, Somali-English bilinguals of a readiness to adopt distinct attitudinal orientations when using one of their languages as opposed to the other,

saying:

The bilingual subject are asked to role-play specified situations in either Somali or in English; and which language they are asked to use turns out to be closely related to such things as how they characterize their own nationality status, how they react to authority figures, what kind of argument style they employ and how many religious values enter their conversation.

He also quotes Ervin-Tripp's (1973) experiment in which a native Japanese, Japanese-English bilingual was asked to interpret a set of pictures, at one point using Japanese and at the other point using English:

...when the subject was asked to respond in his native Japanese as opposed to English, he consistently offered interpretations of more emotional and more achievement-oriented content. 
4. Xu Y. C. (1984a: 137) renders “荅到鳥丝方尽” as “The silkworm till its death spins silk from love-sick

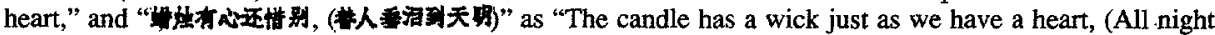
long it sheds tears for us before we part.)" (1984a: 130). Witter Bynner's version runs like this: "Even the candle, feeling our sadness, (Weeps, as we do, all night long.)" (see Lü S. Z. 1980: 80). Rewi Alley (1981: 58) translates the line as "Even the candles share/our emotion, weeping tears (as we do, until the /morning breaks.)."

5. Li Po (701-762), one of the greatest Romantic poets in the history of Chinese literature.

$L i P O$ is a conventional way of transliterating " in " in Roman letters. Spelt in Pinyin, it would be $L i$ $B a i$. However, as $L i P o$ is widely accepted, the conventional transliteration is retained here to avoid confusion. All the other Chinese names are spelt in Pinyin.

6. This line "(Gùrén xî cî Huânghè Lóu), Yânhuã sănyuè xià Yấngzhöu" is rendered by Xu Y. C. (1984a: 34) as "(My friend has left the west where the Yellow Crane Towers) For Yangzhou in spring green with willows and red with flowers." Other renderings are found in Weng Xian Liang (1981: 15):

The smoke-flowers are blurred over the river. (Ezra Pound)

In March, among smoking flowers, making your way to Yangzhou (The White Pony)

He leaves for Yang-chou in the third moon of the spring. (Liu Shi Shun)

'Mid April mists and blossoms go,... (John Turner)

7. Kawahata Yasunari terms such contact as "the forming of ties between the text and the reader," see Otsuka (1977: 106).

8. Here the divergence of the situation is not taken into consideration. In reality, the same situation may impress individuals differently. When an individual notices some features of a particular situation he misses the others. In his interpretation of the perceived data, he relates the data, consciously or subconsciously, only to the situational features retained in his impressions. Cf. Grace (1982: 14); Rumelhart 1979: 85).

\section{REFERENCES}

ALLEN, J. P. B. and S. PIT CORDER (Eds.) (1974): Techniques in Applied Linguistics: the Edinburgh Course in Applied Linguistics, Vol. 3, London, Oxford University Press.

AL,LEY, Rewi (1981): Selected Poems of the Tang and Song Dynasties, Hong Kong, Hai Feng Publishing Company.

AMOS, Flora Ross (1920): Early Theories of Translation, New York, Octagon Books.

AYER, A. J. (1936): Language, Truth and Logic, Harmondsworth, Penguin Books Ltd.

BA.O, Zhen Nan (1982): "A New Approach to Translation Studies-review on Catford's A Linguistic Theory of Translation", China Translation Press (CTP), (Ed.) (1983b), pp. 62-74.

BASSNETT-MCGUIRE, Susan (1980): Translation Studies, London, Methuen.

BLOOM, Alfred H. (1981): The Linguistic Shaping of Thought: a Study in the Impact of Language on Thinking in China and the West, New Jersey, Lawrence Erlbaum Associates.

BLOOMFIELD, Leonard (1914): Language, tr. Yuang Jia Hua et al., Beijing, The Commercial Press (1980).

BROWER, Reuben A. (Ed.) (1959): On Translation, Cambridge (Mass.), Harvard University Press.

CATFORD, J. C. (1965): A Linguistic Theory of Translation, London, Oxford University Press.

CHAO, Y. R. (1969): "Dimensions of Fidelity in Translation, with Special Reference to Chinese," Aspects of Chinese Sociolinguistics, California, Stanford University Press (1976), pp. 148-169.

CHAO, Y. R. (1968): A Grammar of Spoken Chinese, Berkeley, University of California Press.

CHAO, Y. R. (1980): Language Problems, Beijing, The Commercial Press.

CHASE, Stuart (1956): “Foreword"' to Language, Thought and Reality: Selected Writings of Benjamin Lee Whorf, John B. Carroll (Ed.), MIT and John Willey and Sons Inc., pp. v-x.

CHEN, Zhong Sheng (1984): Tidbits of Chinese-English Word Translation, China, Jilin People's Press.

China Translators Association (CTA) and the Editorial Department of Translator's Notes (EDTN) (Eds.) (1984): A Collection of Essays in Translation Studies, 1894-1948, Beijing, Foreign Language Teaching Press.

CTP (Ed.) (1983a): A Collection of Essays on Translation Theory and Techniques, Beijing, CTP.

CTP (Ed.) (1983b): Reviews on Foreign Translation Studies, Beijing, CTP.

DILLON, George L. (1977): Introduction to Contemporary Linguistic Semantics, New Jersey, Prentice-Hall, Inc.

Editorial Department of Heilongjiang College Journal (EDHCJ) (Ed.) (1982): Reviews on Chomsky's Linguistic Theory, Heilongiiang University Press.

Editorial Departments of Foreign Languages and Translations (EDFL\&T) (Ed.) (1984): On Translation, China, Jiangsu People's Press.

FAN, Cun Zhong (1984): "On Translation," in EDFL\&T (Ed.), pp. 92-112.

FIGUEROA, John (1982): "Translating Poetry: Theoretical Considerations Together with Some Examples of Translations from Horace," Problems in Translation, pp. 68-98.

FISIAK, Jacek (Ed.) (1981): Contrastive Linguistics and the Language Teacher, Oxford, Pergamon Press.

FODOR, Janet D. (1977): Semantics: Theories of Meaning in Generative Grammar, Cambridge, Massachusetts, Harvard University Press. 
GRACE, George W. (1982): "Thoughts on Translation and Meaning: a Progress Report," Working Papers in Linguistics, vol. 14, $\mathfrak{n}^{\circ} 3$, Sept-Dec., Department of Linguistics, University of Hawaii, pp. 1-23.

GREENBERG, Joseph H. (Ed.) (1962a): Universals of Language, Massachusetts, The MIT Press.

GREENBERG, Joseph H. (Ed.) (1962b): "Some Universals of Grammar with Particular Reference to the Order of Meaningful Element," in Greenberg (Ed.) (1962a), Chapter V.

GREENBERG, Joseph H. et al. (Ed.) (1962c): "Memorandum Concerning Language Universals," in Greenberg (Ed.) (1962a), Appendix.

HALLIDAY, M. A. K. (1984): "Grammatical Metaphor in English and Chinese," Beverly Hong (Ed.), New Papers on Chinese Language Use, Canberra, The Australian National University, pp. 9-18.

HARTMANN, R. R. K. and F. C. STORK (1973): Dictionary of Language and Linguistics, tr. Huang Chang Zhu et al., Shangai, Shangai Dictionary Press (1981).

HOCKETT, Charles F. (1962): "The Problem of Universals in Language," in Greenberg (Ed.) (1962a), Chapter 1. HONG, Yun Su (1943): "On Translation," in CTA and EDTN (Eds.), pp. 347-352.

HOU, Fang (1982a): "Three Different Periods in the Development of Generative Grammar," in EDHCJ (Ed.) pp. $60-68$

HOU, Fang (1982b): "Some Problems in the Development of Generative Grammar," in EDHCJ (Ed.), pp. 69-92.

HOU, Fang (1982c): "The Governing Theory of Generative Grammar," in EDHCJ (Ed.), pp. 166-184.

HOU, Fang (1982d): "Chomsky's Extended Standard Theory," in EDHCJ (Ed.), pp. 122-138.

JACOBSEN, Bent (1977): Transformational-Generative grammar, Second Revised Edition (1978), Amsterdam, North-Holland Publishing Company.

JACOBSON, Roman (1959): “On Linguistic Aspects of Translation," in Brower (Ed.), pp. $232-239$.

JI, Guo Qing (1982): "The Development and Status Quo of Transformational-Generative Semantic Theory," in EDHCJ (Ed.), pp. 185-207.

JIANG, Wen Xia (1985): "On the English-type Expressions in Canadian French," Foreign Languages Teaching and Research (1985-1), pp. 20-23.

JIN, Di and Eugene A. NIDA (1984): On Translation: with Special Reference to Chinese and English, Beijing, CTP. KONG, Li (1962): Lin Shu and His Fictional Translations, Beijing, Zhong Hua Book Company.

LEECH, Geoffrey and Jan SVARTVIK (1974): A Communicative Grammar of English, London, Longman.

LEI, Hai Zong (1951): "A Historical Approach to Translation Theory and Techniques," in CTP (Ed.) (1983a), pp. 250-256.

LI, Dong (1985): "On the Semantic Problems of the English Derivative Affixes," Foreign Languages, 35: 14-15.

LI, Pei En (1935): "On Translation," in CTA and EDTN (Eds.), pp. 278-286.

LIN, Ye (1986): "Talk to One's Own Soul - Review on The Reverie of a Lonely Walker," The Liberation Daily, March 4, p. 4.

LIU, Bing Zhang (1983): "Random Remarks on the Rendering of Journalistic English into Chinese," in CTP (Ed.) (1983a), pp. 145-163.

LIU, Yong Quan (1984a): "The System of Intermediate Constituents in Machine Translation from Foreign Language into Chinese," Beverly Hong (Ed.), New Papers on Chinese Language Use, Canberra, The Australian National University, pp. 19-32.

LIU, Yong Quan (1984b): "Language Use and Modernisation - The Study of Chinese Information Processing," Beverly Hong (Ed.), New Papers on Chinese Language Use, Canberra, The Australian National University, pp. 33-44.

LOVETT, Maureen W. (1981): "Reading Skill and Its Development: Theoretical and Empirical Considerations," in Mackinnon and Waller (Eds.), pp. 1-37.

LUO, Shu Si (1950): “An Introduction to Tytler's Theory on Translation," in CTP (Ed.) (1983b), pp. 13-20.

LUO, Xin Zhang (Ed.) (1984); Essays on Translation, Beijing, The Commercial Press.

LURIA, Alexander R. (1981): Language and Cognition, James V. Wertsch (Ed.), New York, John Wiley and Sons.

LÜ, Shu Xiang (1980): An English Translation of 100 Tang Poems, China, Hunan Education Press.

LYOVIN, Anatole (1982): "Language Typology and Problems of Translation: the Case of Chinese Poetry Translation," Working Papers in Linguistics, Vol. 14, n 3, Sept.-Dec., Department of Linguistics, University of Hawaii, pp. 21-37.

MA, Jian Zhong (1894): "A Proposal for Setting Up a Translation Academy," in CTA and EDTN (Eds.), pp. 1-5.

MA, Zu Yi (1984): A History of Chinese Translation: Up to the May 4th Movement, Beijing, CTP.

MACKINNON, G. E. and E. Gary WALLER (Eds.) (1981): Reading Research: Advances in Theory and Practice, Vol. 3, New York, Academic Press.

MATTHEWS, Jackson (1959): “Third Thoughts on Translating Poetry," in Brower (Ed.), pp. 67-77.

MORALES, Humberto Lopez (1982): "Deep Structure, Surface Structure and translation," Problems in Translation, pp. 12-27.

MUIR, Edwin and Willa MUIR (1959): "Translating from the German," in Brower (Ed.), pp. 93-96.

NEWMARK, Peter (1981): Approaches to Translation, Oxford, Pergamon Press. 
NIDA, Eugene A. (1959): "Principles of translation as Exemplified by Bible Translating," in Brower (Ed.), pp. 11-31.

NIDA, Eugene A. (1964): Toward a Science of Translating: with Special Reference to Principles and Procedures in Bible Translation, Leiden.

NIDA, Eugene A. (1969a): "Science of Translation," Language, 45, pp. 483-498.

NIDA, Eugene A. (1975): Language Structure and Translation: Essays by Eugene A. Nida, selected and introduced by Anwar S. Dil, California, Stanford University Press.

NIDA, Eugene A. (1982): Translating Meaning, San Dimas, Califomia, English Language Institute.

NIDA, Eugene A. and C. R. TABER (1969b): The Theory and Practice of Translation, Leiden.

NLDA, Eugene A. and William D. REYBURN (1981): Meaning Across Culture, Maryknoll, New York, Orbis Books.

O'NEIL, Wayne (1981): English Transformational Grammar, tr. Zhang Yun Fei et al., Beijing, Beijing Normal University Press.

ORTONY, A. (Ed.) (1979a): Metaphor and Thought, London, Cambridge University Press.

ORTONY, A. (1979b): "Metaphor: A Multidimentional Problem," in Ortony (Ed.) (1979a), pp. 1-16.

OTSUKA, Yukio (1977): Principles of Comparative Literature, tr. Chen Qiu Feng and Yang Guo Hua, China, Shanxi People's Press.

PALMER,L. R. (1936): An Introduction to Linguistics, tr. Li Rong et al., Beijing, The Commercial Press.

PENG, Qi Liang (1980): Translation and Comparison, Beijing, The Commercial Press.

POGGIOLI, Renato (1959): "The Added Artificer," in Brower (Ed.), pp. 137-147.

Problems in Translation, Editorial de la Universidad de Puerto Rico (1982).

QIAN, Zhong Shu (1979a): Four Essays Reprinted, Shangai, Shangai Ancient Books Publishing House.

QLAN, Zhong Shu (1979b): A Collection of Literary Criticisms, Beijing, Zhong Hua Book Company.

QIAN, Zhong Shu et al. (1981): On Lin Shu's Translations, Beijing, The Commercial Press.

REN, Xue Liang (1981): A Comparative Grammar of Chinese and English, Beijing, China Social Press.

ROSE, Marilyn G. (Ed.) (1981a): Translation Spectrum: Essays in Theory and Practice, Albany, State University of New York Press.

ROSE, Marilyn G. (1981b): "Introduction: Time and Space in the Translation Process," in Rose (Ed.) (1981a), pp. $1-7$.

ROSENBERG, J. F. (1974): Linguistic Representation, Dordrecht, D. Reidel Publishing Company.

ROSS, Stephen D. (1981): "Translation and Similarity," in Rose (Ed.) (1981a), pp. 8-22.

RUMELHART, David E. (1979): "Some Problems with the Notion of Literal Meanings," in Ortony (Ed.) (1979a), pp. 78-90.

SJAVAARA, Kari (1981): "Psycholinguistic Models, Second-language Acquisition and Contrastive Analysis," in Fisiak (Ed.), Chapter VII.

SANDERS, Carol (1981): "Recent Developments in Contrastive Analysis and Their Relevance to Language Teaching," in Fisiak (Ed.), Chapter III.

SAPIR, Edward (1921): Language: an Introduction to the Study of Speech, New York, Harcourt, Brace and Company.

SAUSSURE, Ferdinand de (1916): Cours de linguistique générale, tr. Gao Ming Kai, Beijing, The Commercial Press (1980).

SAVORY, Theodore H. (1957): The Art of Translation, London, Jonathan Cape.

SHI, Si Ren (Ed.) (1981): A Selection of Essays on Lexicography, Beijing, The Commercial Press.

SHIERBA, P. B. (1981): "An Approach to the General Theory of Lexicography," in Shi S. R. (Ed.), pp. 3-57.

SNYDER, William H. (1981): "Linguistics and Translation," in Rose (Ed.) (1981a), pp. 127-134.

SOUKALIENKO, H. H. (1981): "The Corresponding Variants in Translation," in Shi S. R. (Ed.), pp. 188-209.

SRIDHAR, S. N. (1981): "Contrastive Analysis, Error Analysis and Interlanguage: Three Phases of One Goal," in Fisiak (Ed.), Chapter XIV.

STEINER, George (1975): After Babel: Aspects of Language and Translation, London, Oxford University Press.

STRAIGHT, H. Stephen (1981): "Knowledge, Purpose, and Intuition: Three Dimensions in the Evaluation of Translation," in Rose (Ed.) (1981a), pp. 41-51.

ULLMAN, Stephen (1962): "Semantic Universals," in Greenberg (Ed.) (1962a), Chapter VIII.

WANG, Yi Zhu (1981): "On the Untranslatability of Poems," in CTP (Ed.) (1983a), pp. 190-204.

WANG, Zong Yan (1982): "Newmark on Translation Theory and Techniques," in CTP (Ed.) (1983b), pp. 1-12.

WANG, Zuo Liang (1979): "Meaning, Stylistics and Translation," in CTP (Ed.) (1983a), pp. 51-61.

WENG, Xiang Liang (1983): Can Spirit Never Be Painted? Beijing, CTP.

WERTSCH, James V. (1981): "Editor's Introduction," Language and Cognition, in Luria.

WHORF, B. L. (1956): Language, Thought and Reality: Selected Writings of Benjamin Lee Whorf, John B. Carroll (Ed.), MIT, John Wiley and Sons, Inc.

WIDDOWSON, H. G. (1983): "Widdowson on Literature and English Language Teaching," ELT Journal, Vol. 37. WILSS, Wolfram (1982): The Science of Translation: Problems and Methods, Gunter Narr Verlag, Tübingen. 
XIAO, Jun Shi (1982): An Approach to the Translation from Chinese into English and Vice Versa, Beijing, The Commercial Press.

XU, Yuan Chong (1984a): 150 Tang Poems with English Renderings, China, Shanxi People's Press.

XU, Yuan Chong (1984b): The Art of Translation, Beijing, CTP.

YANG, Da Ying (1985): "On the Rhetorical Function of Huwen," Rhetoric (1985-1), pp. 14-15.

YANG, Zhen Hua (1935): "Translation Studies," in CTA and EDTN (Eds.) (1984), pp. 287-316.

YE, Fei Sheng and Xu Tong QIANG (1981): Essentials of Linguistics, Beijing, Beijing University Press.

ZENG, Xu Bai (1928): "The Difficulties of Translating," in CTA and EDTN (Eds.) (1984), pp. 144-149.

ZENG, Xu Bai (1930): "Literary Charm and Expressiveness in Translation," in CTA and ETDN (Eds.) (1984), pp. 150-156.

ZHANG, Jin and Yun Qing CHEN (1981): Essentials of the Comparative Grammar of English and Chinese, Beijing, The Commercial Press.

ZHANG, Long Xi (Ed.) (1982): A Selection of Essays on Comparative Literature, Beijing, Beijing University Press. ZHAO, Zhi Yi (1981): A Comparative Grammar of English and Chinese, China, Shanxi People's Press.

ZHENG, Ding Ou (1985): "A New Phase in the Development of Structuralistic Linguistics - an Introduction to the French Distributional Grammar," Foreign Languages (1985), Vol. 35, pp. 73-77.

ZHU, Guang Qian (1980): A Selection of Zhu Guang Qian's Essays on Aesthetics, China, Hunan People's Press. 